UDC 94(477.6)"18"/"19"=411.16)

\section{Oleg POSTERNAK}

Izmail State Liberal Arts University, Izmail (Ukraine), idgu-ukrist@yandex.ru

\section{SOCIAL AND POLITICAL SITUATION \\ OF THE JEWISH POPULATION IN THE}

SOUTHERN BESSARABIA

IN THE SECOND HALF OF THE XIX -

EARLY XX CENTURIES
Ключевые слова: евреи, юг Бессарабии, дискриминация, сионизм, партии.
Постернак О. Социально-политическое положение еврейского населения Юга Бессарабии во второй половине XIX - начале XX в.

Рассматривается социально-политическое положение еврейского населения южных уездов Бессарабской губернии во второй половине XIX - начале $\mathrm{XX}$ в., исследуется специфика российской национальной политики по отношению к евреям региона, их участие в деятельности политических партий, ход еврейских погромов в городах и селах края.
The today's potential of historiography provides an opportunity to understand the underlying processes and forces of society in terms of capitalist modernization of the second half of the nineteenth - early twentieth century more precisely. However, the event-driven palette of effects and processes can be fully understood only if to take into account its realization and perception by different social and ethnic groups. One of such groups was the Jewish population, which occupied a special position in the Russian Empire. In 1897 the Jews of the Russian Empire constituted almost half (49\%) of the total number of Jews in the world ${ }^{1}$. In this article we will focus on the socio-political position of the Jews of Bessarabia south, which at that time included Akkerman and Izmail counties.

The relevance of the research is supported by the state of scientific development problems. Sustained interest in the Jewish question in Russia arose in the nineteenth century. General works of historians and writers of the XIX - early XX century touched upon such problems as legislation on the Jews, their social, religious and economic life ${ }^{2}$. Soviet historical science practically brought the history of Jews in the Russian Empire out of research interest's brackets. These gaps were filled in the modern historical tradition ${ }^{3}$.

The Jews were practically not associated with traditional farming identity, which was a characteristic for the majority of the population in the empire. Focusing on commercial and usurious forms of activity, Jews' attraction to intellectual pursuits created the original distinctive ethnic group. However, the whole history of the Jewish people from ancient times until the latest time is full of persecution, massacres and repression. All this have left an indelible mark on the collective consciousness of the people. The historian I. Zhitetsky said: "The oppression, forcing Jews to exert their physical and spiritual strength to support their existence and defend the national and religious identity among hostile ethnic groups, has developed a keen penetrating mind of the Jews, resistance, power; oppression trained their sobriety and frugality, reinforced the Jews family virtues, but, on the other hand, pressure has developed negative moral qualities of the Jews: deception, flattery, servility, cunning, resourcefulness. It contributed to greater isolation of the Jews from the rest of humanity"4.

A large part of the Jewish population of the Empire lived in the South-West of Russia, which, including the province of Bessarabia, represented a huge territorial array, referred to as "Border-line of Jewish Settlement." Formation of the Jewish community in the era of its stay in the Russian Empire refers to the first half of the nineteenth century. As reported by P. Svin'in, in 1816 in Bessarabia Jews numbered about five thousand families. According to him, they took part in all paying off and kept villages in a rental ${ }^{5}$. A census of church authorities in 1858 indicates that there were 61 thousand Jews in Bessarabia (7.2\% of the 
province's population). In the late nineteenth century Bessarabia occupied the fourth place among all the provinces of European Russia with the highest proportion of the Jewish population. Then in 1897 there were approximately 228 thousand Jews $(11.8 \%$ of the total population of the province).

At the end of the nineteenth century Jews in Bessarabia were the third largest ethnic group after Moldovans and Ukrainians. The Jewish population inhabited compactly northern and central regions of the province. The highest percentage of Jews was in Chisinau (19.5\%), Khotyn (15.6\%) and Soroka $(14.1 \%)$ counties ${ }^{6 .}$ In the south of Bessarabia population included 23,995 Jews, which represented $10.5 \%$ of the total number of Jews in the province. The main part of the Jews lived in cities. Most of them were in Akkerman (5573 people), Izmail (2736 people) and Kiliya (2144 people).

Demographic dynamics can be analyzed by comparing the statistics on the number of Jews in the Bessarabia's south of the early 80 's in the nineteenth century with the census of 1897 . In the Akkerman district in the early 80s there were 7731 Jews (3.9\% of the population of the county), in Akkerman - 3459 (7.6\% of the population of the city), in towns - 1016 (18.3\% of the population of towns), in villages -3256 (2.2\% of the population of villages), in Izmail district -6270 Jews (4\% of the population of the county), in Izmail -1302 ( $4.3 \%$ of the population of the city), in the towns $-4410(12.4 \%$ of the population of towns) in villages $-558(0.6 \%$ of the population in the villages) $)^{7}$. Thus, the density of the Jewish population was higher in villages - ancient centers of their placement. The number of Jews in the two southern districts of Bessarabia in 1897 comparing to the early 80 s of the XIX century has increased almost twice. Increase of the Jewish population was the result of natural increase. In addition, Jewish families were, as a rule, large and consisted of representatives of several generations.

Imperial policy regarding the "Jewish Question" in the region had a dual character. On the one hand, the tsarist autocracy was interested in colonizing the region, joined to Russia in 1812 , in the admission of local Jewry to the all-Russian civic order, excommunication from the religious fanaticism. On the other hand - it could not ignore the fact that the concentration of land holdings in the hands of the Jews led to speculation, limitation of the farms areas and would cause ethnic and religious conflicts.

In the nineteenth century special decrees and resolutions for the Jews of Bessarabia were issued, aiming at limiting their participation in economic and political life, limiting freedom of movement and residence, certain activities, etc. Such a discriminatory policy against the Jews is rightly assessed in science as ethnic segregation ${ }^{8}$. Under the "Temporary Rules" (May 3, 1882) Jews were forbidden to settle outside of towns and villages (except for the Jewish settlers), their ability to acquire and lease lands, to trade on Sundays and during religious holidays was limited. "Rules" also included the restriction of civil and voting rights and the imposition of interest rules for Jews in schools. In Bessarabia government began to drive Jews from rural areas into cities and towns ${ }^{9}$. The increased Jewish population in the cities, their predominant focus on trade and industrial activity in its turn led to an anger accumulation of the indigenous urban population which, understandably, led to outbreaks of antiSemitism.

The Jewish question received a special actualization in the early 80s of the XIX century, when Russian provincial commissions began to arrange meetings on this occasion. Such a commission was also formed in Bessarabia. It noted the fact of Jewish isolation in the region, which was supported by existing legislation. The commission was in favor of the abolition of discriminatory taxes, abolition of Cheders and posts of the official rabbi, the introduction of the teaching of Judaism in general educational institutions. Commission considered limitation of the number of Jews among university students to be inappropriate. It also supported the permission for Jews to settle outside the demarcation line. According to commission members, all of this was to facilitate the convergence of the Jewish nation with the Russian society. However, some conclusions were openly conservative. Thus, the majority of commission members voted for prohibition of the foreign Jews' entry in Russia, for providing rural communities the right to evict the Jews, for the prohibition to lease and buy land less than 500 acres.

In discussing of the need for the expulsion of Jews from the countryside volostnye wardens of the southern Bessarabia hold a very reactionary position. Thus, the volostnoy warden of the Akkerman county Motuzenko stated that the Jews in the countryside are harmful, and therefore they should not be allowed to live in villages and towns due to the fact that "they sell the goods ... at very high prices." "The Jews stick round village like phylloxera sticks round vine root" - summarized the volostnoy warden. The head of one of the rural communities of Izmail district Stoyalovsky also supported this point of view, saying that Jews "make money in advance, at the expense of the next harvest, and at 4 rubles lower than the 
prices during the harvest." The representative of the Jews in Grimberg Commission noted that "the harm from the Jews was exhibited in the most striking features by those wardens, who had almost no Jews in their lands (Akkerman, Bendersky and Izmail counties); at that time wardens of Orgeevsky and Soroksky counties, as well as mayors of Balti and Sorok do not see any harm in them" ${ }^{10}$. The position of volostnyh wardens indicates the predominant influence of economic motives on shaping the Jew-hatred tradition among the Christian population, rather than historical, cultural, mental, or religious ones. Provincial authorities connived at the attempts to present the Jews guilty for misfortunes of the local peasantry, which came from the lower classes. The Jews were a convenient substitute for social hatred of the peasant class.

Social conditions of a large part of the Jews, according to L.S. Berg, were extremely bad. $\mathrm{Gen}^{11}$. Urban Jewish population was vividly described by Bessarabian governor S.D. Urusov in 1907: "The number of Jewish signs on the streets of Bessarabian cities affects the observer. Houses of even minor and provincial streets are crammed with shops, workshops of watchmakers, shoemakers, locksmiths, tailors and carpenters, etc. Working people are huddling in the corners and crannies in the crush of poverty, affecting the observer, producing their daily sustenance with difficulty, in which a rusty herring with onions is the sign of luxury and prosperity" ${ }^{12}$. On the other hand, the urban life helped to overcome the patriarchal system, to form the Jewish intelligentsia and many of revolutionaries.

In the late XIX - early XX century rapid decay of the traditional society was going, which affected also the Jews: emigration, the desire to pursue higher education, the proletariazation of the population. All this contributed to the involvement of the Jewish population in the political struggle. The Jewry was considered to be a leading participant in Jewish revolutionary movement in the empire. The overall growth of opposition speeches in the early XX century defined the process of political self-organization among the Jewish population.

One of the leading Jewish political parties was the Bund ("General Jewish Workers' Union of Lithuania, Poland and Russia), formed in 1897. Supporters of the Bund had mainly the socialdemocratic slogans, but also documented claims of providing Jewish national-cultural autonomy in their compact residence were founded in their program. In Bessarabia the organization of the Bund was founded in February 1904 by separation

АПСНIM. - 2015. - № 2 (6) from Chisinau organization of the RSDLP. It was led by Maria Uchitel.

A historian I. Budak pointed out that Bundist influence in the social-democratic organizations of the province was quite strong ${ }^{13}$. It touched upon the political life of Izmail. The political report of the provincial chief of gendarmes (1906) stated, for example, that an employee of the Russian Bank of Foreign Trade in Izmail Granich stole about 20 thousand rubles. According to police, these funds were intended for the monetary fund of the Bund. Granich, who had conducted an active propaganda work among the local Jewish population, was forced to leave Russia ${ }^{14}$. The researcher K. Slutskaya, unfortunately without appropriate references on sources, said that during the First World War there were separate party organizations of the RSDLP and the Bund in Izmail $^{15}$.

In the Russian Empire, in contradistinction to Western Europe and the U.S., the Jews were not emancipated and assimilated by the state society. This has created a strong platform for the Zionist movement, one of which centers was located in the Russian Empire ${ }^{16}$. In the south of Bessarabia the Zionists-Socialists spread their influence. The Zionist Socialist Workers' Party became a competitor for the Bund. The organization publicshed a newspaper "Evreysky Golos" in Odessa and had a significant impact on the local population of the province. Thus, the head of the Bessarabian Provincial Gendarmerie in 1906 wrote that in Bessarabia "except for the Bund, there are separate organizations of the Zionist-Socialist Workers Party" ${ }^{17}$. In their program Zionist Socialists insisted on the necessity to recognize the legal rights of the Jewish population, on the formation of national self-government, on the use of ethnic language in national schools, legal institutions and in public life, on the preservation of traditional norms of Jewish law and on the establishing of the All-Russian Jewish national assembly ${ }^{18}$.

Gendarmes could find the location of the main "Zionist settlements" of the party in rural and urban arias of the region. Thus, the Zionists in Bolgrad included I. Pintel, in Akkerman - L. Herbert Marcuse, M. Komorovsky, L. Kogan, Gelfek; in Bayramche - a teacher I. Glazman, in Tatarbunary - a head of school D. Kidryanu. Zionist centers existed in other places of Bessarabia, in particular, in Chisinau, Brichevo, Briceni, Attacks Lipcani ${ }^{19}$. It should be emphasized that in the south of Bessarabia influence of Zionists-Socialists was more effective than the Bund. This is explained by the fact that the Bund was oriented in its activities predominantly on the workers and artisans, whose number was quite insignificant in 
the region, and the Zionists-Socialists, who put national slogans in the first place, enjoyed the support of a significant number of Jewish bourgeoisie and traders.

Other Jewish political structures demonstrated less activity in Bessarabia. According to the Bessarabian Provincial Gendarmerie, the Jewish Social-Democratic Party "Poalei Zion" (Workers of Zion) acted in the province. It was founded in Switzerland in 1905. Its mission was based on the political organization of workers in order to revive a democratic Jewish state in Palestine. A local cell of the Jewish National Union "Der Greyher" also had a certain influence in the province of Bessarabia. A goal of the organization was to achieve full equality between the Jewish people ${ }^{20}$. However, these political forces were characterized by the absence of a strong party center and a broad organizational hierarchy.

Jews were often met among separated groups of anarchists who started a broad terrorist propaganda activity in southern Russia. Thus, in Akkerman the local anarchist group included M. Mather and C. Krasner. The latter, according to police, was "ardent revolutionary," known for its connections with various anti-government organizations in other cities ${ }^{21}$. Bomb blast in Akkerman in June 1906, which happened during its preparation in an apartment of S. Hershkowitz, allowed the police to detect a trace of the local anarchist cell. It was proved that the bomb shell belonged to explosive devices, used exclusively by anarchists. The daughter of Hershkowitz, R. Greenberg, was arrested ${ }^{22}$.

The growth of political consciousness of the Jewish population made conservative chauvinistic circles concerned - they hoped to turn Bessarabia into bastion of a regime. Blaming the Jews for promoting the revolution and the destruction of indigenous monarchical principles of statehood, "chernosotentsy" only in Bessarabia 1905-1906 committed 71 massacres with the largest number of victims in the south-west of the Empire - $942^{23}$. On October 22-24, 1905 "chernosotentsy" carried out a massacre in the central quarters of the city of Izmail. About 220 commercial and residential buildings were destroyed. As pointed out by archival documents, the actions of the "right" political forces have caused huge losses to local Jews and some of them were forced to curtail its business activities ${ }^{24}$. From 22 to October 25, 1905 a massacre was carried out in Kilia, in which 7 persons were killed and 14 were wounded ${ }^{25}$.

Anti-Semitic practice of "chernosotentsy" became extremely powerful in Akkerman district. For example, in the village of Kaplans shops and grocers of Jews Shihverger and Pasatyr were looted. Massacres also affected Jewish merchants of villages Raylyanka, Kamchik, Kebabcha, Akimbeta. In the town of Bayramcha 11 shops and 12 houses for a total of $\$ 81760$ rubles were destroyed ${ }^{26}$. At Chabot after the monarchist demonstration radical youth began to smash Jewish stores, shops, beat box, utensils and furniture. This was the reason for the numerous appeals of the local Jews to the Shabo Posad warden with the requirement to establish order ${ }^{27}$.

Thus, the Jews in the southern Bessarabia became a classic example of the struggle for survival of an ethnic minority in the foreign environment. Patriarchal way of life and conservative political consciousness did not allow society to value the essence of the "Jewish question." A public power exercised social and ethnic exclusion of Jews, which led to the growth of radical political consciousness in the early $\mathrm{XX}$ century. The lower the level of integration into the Russian imperial identity was, the greater the potential opposition to the existing political regime became. Dissatisfaction with this phenolmenon has resulted in outbreaks of ethnophobia in the form of massacres, which covered the region during the 1905-1907 revolution.

\section{References:}

1 Западные окраины Российской империи / Л.А.Бережная, О.В.Будницкий, М.Д.Долбилов и др. - М. : Новое литературное обозрение, 2006. -608 c. - c. 304.

${ }^{2}$ Берлин М. Очерк этнографии еврейского народонаселения в России / Моисей Берлин. СПб. : Тип. В.Безобразова и К, 1861. - XII, 91, [1] с.; Оршанский И.Г. Евреи в России. Очерки экономического и общественного быта русских евреев / И.Г. Оршанский. - СПб. : Тип. О.И. Бакота, 1877. - 439 с.; Гессен Ю.И. Евреи в России. Очерки общественной и ікономической жизни русских евреев / Юлий Исидорович Гессен. - СПб. : скл. изд. при Юрид. кн. скл. «Право», 1906. - VI, 471 с.

${ }^{3}$ Хонигсман Я.С. Найман А.Я. Евреи Украины: Краткий очерк истории. Ч. I / Я.С. Хонигсман, А.Я. Найман - Киев : [б. и.], 1992. 158 с.; Самарцев І.Г. Евреї в Україні на початок XX ст. / І.Г. Самарцев // Український історичний журнал. - 1994. - №4. - С.19-29 ; Морозова А.В. Єврейське населення Лівобережної України (друга половина XIX - початок XX ст.) : автореф. дис. на здобуття наук. ступеня канд. іст. наук : спец. 07.00.01 «Історія України» / А.В.Морозова. - Харків, 2005. - 24 с.; Гончаров В.В. Сврейське населення Південно-Східної України 1861-1917 рр. : автореф. дис. на здобуття наук. ступеня канд. іст. наук : 
спец. 07.00.01 «Історія України» / В.В.Гончаров. - Донецьк, 2005. - 20 с.; Шитюк М.М. Щукін В.В. Єврейське населення Херсонської губернії в XIX - на початку XX століть / М.M. Шитюк, В.В.Щукін. - Миколаїв : Вид-во Ірини Гудим, 2008. - 221 с.

4 Житецкий И. Евреи в южной России. Формы труда у евреев в южной России. (Историко-этнографические заметки) / И. Житецкий // Киевская старина. - 1901. - T. LXXIV. - С.145. - C.6-7.

${ }^{5}$ Свиньин П.П. Описание Бессарабской области. Составлено ведомства государственной коллегии иностранных дел надворным советником Павлом Свиньином, 1816 года, 1го июня / Свиньин П.П. // Записки Одесского общества истории и древностей. - 1867. - T.VI. - C.175-320. - C.207.

${ }^{6}$ Зеленчук В.С. Население Бессарабии и Поднестровья в XIX в. : (Этн. и социал.-демогр. процессы) / Валентин Степанович Зеленчук. - Кишинев : Штиинца, 1979. - 287 с. C.156, 208-209.

${ }^{7}$ Аленицин В.Д. Еврейское население и землевладение в юго-западных губерниях Европейской России, входящих в черту еврейской оседлости : [обраб. по порученю высочайше учрежденной Высш. коммис. для пересмотра действующих о евреях в Империи законов] / Владимир Дмитриевич Аленицин. СПб. : Гос. тип., 1884. - XVI, 79, [4] с. - С.2-3.

${ }^{8}$ Базаров О.Т. Політика російського уряду в єврейському питанні наприкінці XIX століття (1881-1894 рр.) : автореф. дис. на здобуття наук. ступеня канд. іст. наук : спец. 07.00.02 «Всесвітня історія»/ О.Т. Базаров. Чернівці, 2003. - 28 с. - С. 14.

${ }^{9}$ Урусов С.Д. Записки губернатора. Кишинев. 1903-1904 г. / Сергей Дмитриевич Урусов. - [М.], В.М.Саблин, [1907]. - 377 с. - с. 298. C.299.

${ }^{10}$ Труды губернских комиссий по еврейскому вопросу. - СПб. : Тип. Мин. внутр. дел, 1884. - Ч.2. Губернии: Харьковская, Екатеринославская, Киевская, Таврическая, Волынская, Бессарабская, Полтавская, Херсонская с Одесским градоначальством и Подольская. 1884. - X, 1242, 127 c. - C.702-72, 740, 752. C. $739,743,746,762,764$.

${ }^{11}$ Берг Л.С. Бессарабия. Страна-люди-хозяйство. [С карт. и 30 рис.] / Лев Семенович Берг. - Пг. : Огни, 1918. - VIII, 242, [2] с. C.134.

12 Урусов С.Д. Записки губернатора. Кишинев. 1903-1904 г. / Сергей Дмитриевич Урусов. - [М.], В.М.Саблин, [1907]. - 377 с. c. 304-305.
${ }^{13}$ Будак И.Г. Общественно-политическое движение в Бессарабии в пореформенный период / Илья Григорьевич Будак. - Кишинев : Картя Молдовеняскэ, 1959. - 412 с. - С.352353.

${ }^{14}$ Коммунальное учреждение «Измаильский архив» (КУИА), ф.1172, оп.1, д.11, л.24.

${ }^{15}$ Иванов Ю.Г. Революционное движение в Молдавии (с 1895 по февраль 1917 г.) / Юрий Григорьевич Иванов. - Кишинев : Штиинца, 1980. - 240 c. - C. 173.

${ }^{16}$ Гаухман М.В. Російська національна політика щодо єврейського питання в Правобережній Україні (1905-1914рp.) / М.В. Гаухман // Вісник Луганського національного університету ім. Тараса Шевченка. - 2010. - № 19 (206). - C.166-177. - C.171.

${ }^{17}$ История Молдавии : Документы и материалы / [сост. Ю. Г. Иванов, А. П. Лисовина, И. И. Немиров и др.]. - Кишинев : Штиинца, 1961. - Т. 5: Крестьянское движение в Молдавии эпохи империализма. - 1961. - 599 с. C.234.

${ }^{18}$ КУИА, ф.1007, оп.1, д.26, л.114-115.

${ }^{19}$ КУИА, ф.1007, оп.1, д.33, л.3.

${ }^{20}$ История Молдавии : Документы и материалы... - С.256-257.

${ }^{21}$ Революционное движение в Придунайском крае. 1900-1017 гг. : Документы и материалы. - Одесса : Маяк, 1973. - 219 с. C.121-122.

${ }^{22}$ КУИА, ф.1172, оп.1, д.3, л.1.

${ }^{23}$ Гаухман М.В. Російська національна політика щодо єврейського питання в Правобережній Україні (1905-1914 pp.)... - С.169.

${ }^{24}$ КУИА, ф.2, оп.1, д.429, л.22.

${ }^{25}$ Белобородова А. Генеральная репетиция. Документы рассказывают // Советский Измаил. - 1967. - 17 марта. - С.2.

${ }^{26}$ КУИА, ф.770, оп. 1, д.21, л. 221.

${ }^{27}$ КУИА, ф.757, оп.1, д.14, л.335.

\section{Постернак Олег. СОЦАЛЬНО-ПОЛІ- ТИЧНЕ СТАНОВИЩЕ ЄВРЕЙСЬКОГО НАСЕЛЕННЯ ПІВДНЯ БЕССАРАБІЇ У ДРУГІЙ ПОЛОВИНІ ХІХ - НА ПОЧАТКУ XX CT.}

На матеріалах південних повітів Бессарабської губернії Російської імперії проаналізовано соціально-політичне становище євреїв у другій половині XIX - початку XX ст.

У Російській імперії, на відміну від Західної Європи та США, євреї не були емансиповані й асимілювані у суспільство. Це створило міцну основу для сіоністського руху в центрі Російської імперії. Сіоністи-соціалісти поширили свій вплив на південь Бессарабії. 
Сіоністська соціалістична робоча партія публікувала газету «Голос Єврейський» в Одесі та справила значний вплив на місцеве населення провінції. У своїй програмі сіоністські соціалісти наполягали на необхідності визнати законні права єврейського населення на формування національного самоврядування, використання етнічної мови в національних школах, правових інститутах $\mathrm{i}$ в суспільному житті, збереження традиційних норм єврейського закону $\mathrm{i}$ на встановлення традиційних норм єврейського закону i про створення Всеросійського єврейського національного зібрання.

У статті підсумовано, що соціально-політичне становище єврейського населення на півдні Бессарабії у другій половині XIX - на початку XX ст. стало класичним прикладом боротьби етнічної меншини за виживання в інонаціональному, іноконфессіональному i авторитарному оточенні. Патріархальний побут і консервативна політична свідомість не дозволило суспільству тверезо оцінити суть «єврейського питання». А здійснюване державною владою соціально-етнічне відчуження євреїв привело на початку XX ст. до зростання радикальної політичної свідомості. Чим нижче був рівень інтеграції в російську імперську ідентичність, тим значніше був потенціал опозиційності до існуючого політичного режиму. Невдоволення цим явищем вилилося у спалахи етнофобії у вигляді єврейських погромів, що охопили регіон під час революції 1905-1907 pp.

Ключові слова: євреї, південь Бессарабї̈, дискриміначія, сіонізм, партії. 